\title{
Supply-side structural reforms from the perspective of global production networks - based on the theoretical logic and empirical evidence of political economy
}

\author{
Fusheng Xie and Ling Gao \\ Renmin University of China, Beijing, China, and \\ Peiyu Xie \\ National School of Development, Peking University, Beijing, China
}

\begin{abstract}
Purpose - This paper examines the different features of China's economic development in different stages of economic globalization. The study finds that the investment- and export-based growth model drove China's high-speed economic growth between 2000 and 2007, which came into existence around 2000 when China plugged into the global production network.

Design/methodology/approach - This paper also finds that China slowed down to the New Normal because of the disruption to the socio-economic underpinnings of this growth model. As China adapts to and steers the New Normal, supply-side structural reforms can channel excess capacity to the construction of underground pipe networks in rural areas of central China and fix capital while advance rural revitalization.

Findings - At the same time, enterprises must strive to build a key component development platform for key component innovation and the standard-setting power in global manufacturing.

Originality/value - The establishment of a domestic production network integrating the integrated innovation-driven core enterprises and modular producers at different levels can satisfy the dynamic demand structure of China in which standardized demands and personalized demands coexist.
\end{abstract}

Keywords Production network, Production method innovation, Key component innovation, Rural revitalization

Paper type Research paper

\section{Introduction}

Since the reform and opening-up, China's economy has experienced long-term prosperity and miraculous development [1]. China's production capacity in all aspects has experienced a growth spurt, and a considerable amount of the production capacity was generated during the golden period of world economic growth, facing foreign demands and domestic high-speed growth [2]. With the outbreak of the 2008 financial crisis, the effective demand in the international market shrank sharply. And to cope with the impact of the financial crisis, China expanded its production capacity in some sectors. At present, expedition of technological change, upgrading of consumption structure and deceleration of the international market growth occur all at the same time. A considerable part of China's production capacity

(C) Management World. Published in China Political Economy. Published by Emerald Publishing Limited. This article is published under the Creative Commons Attribution (CC BY 4.0) licence. Anyone may reproduce, distribute, translate and create derivative works of this article (for both commercial and noncommercial purposes), subject to full attribution to the original publication and authors. The full terms of this licence may be seen at http://creativecommons.org/licences/by/4.0/legalcode. Originally published in Simplified Chinese in Management World.

Funding: This article is supported by the "Double First-Class" Beijing University Construction Fund. 
CPE

3,1

94

has peaked, and much of the production capacity cannot be achieved on the market. Besides, production costs are on the rise, which leads to the decline in marginal and average profits of the real economy, and drives a large amount of capital towards the virtual economy. Therefore, the cycle of production, exchange, distribution and consumption in social reproduction cannot run smoothly [3]. China's economy has thus entered a period of deep adjustment, that is, the New Normal. To adapt to and steer the New Normal, and to blaze a new development pathway of higher quality, better efficiency and better structure that can give full play to China's advantages, General Secretary Xi Jinping proposed the strategy of supply-side structural reforms. Growth, quality and efficiency can only come from economic restructuring. Supplyside structural reforms are the essential stabilizer for China's economic growth [4].

Since the introduction of supply-side structural reforms, China's academic circle has done a lot of studies, and they can be roughly grouped into four types. The first type of literature explains the background of supply-side structural reforms - the slowdown of China's economic growth. There are mainly seven theories: transformation of driving forces (Liu, 2016a), distortion of economic structure (Wu, 2016), decline in demographic dividend (Cai, 2016a,b), gear-shifting of industrial development (Wei, 2014, 2017), insufficient technological innovation (Fang, 2016; Fang and Ma, 2016; Li and Zhang, 2015), externalities and economic cycles (Lin, 2016a, b) and lagging system reform (Tian and Chen, 2015; Tian, 2018). The second type of literature describes the theoretical basis of supply-side structural reforms. There are mainly three theories: Marxist political economy (Pang, 2016; Hong, 2016; Xie and Yu, 2016; Fang and Hu, 2016; Zhang, 2017), novel supply-side economics (Jia and Su, 2016) and new theories built on existing theories guided by Marxist political economy (Liu, 2016b; Fang, 2017). The third type of literature points out the structural connotation of supply-side structural reforms. There are mainly six theories, namely, production structure (Li, 2015; Wei, 2018), economic structure (Liu, 2016d), institutional structure (Wu, 2017), industrial structure, regional structure and distribution structure (Huang, 2016; Liu and Cai, 2017; Liu, 2016c), the structure of means of production and consumption in social reproduction (Yang and Zhu, 2018; Fang, 2018) and commodity market structure (Zhou and Liu, 2017). The fourth type of literature emphasizes the design of supply-side structural reforms. This type of literature can be grouped into three kinds. The first kind of theory underscores correctly handling the relationship between supply management and demand management, with debates going on around which is more important (Shen, 2016; Wei and Huang, 2018; Zhang, 2016; Ding, 2016; Chen and Chen, 2016). The second kind of theory emphasizes the significance of innovation, and can be sub-divided into theories about institutional innovation (Liu, 2017; Jin, 2017), technological innovation (Hu et al., 2016; Gong, 2016; Shen and Jin, 2016) and organizational innovation (Zhou and Sheng, 2018). The third kind of theory starts with the global value chain and highlights the importance of manufacturing upgrading (Shen and Li, 2017).

The literature mentioned above has increased our understanding of supply-side structural reforms. However, there are still deficiencies in the following three aspects. First, the previous studies failed to consider the fact that the rapid growth since China's reform and opening-up began around 2000, and that the structural issue of the New Normal originated from the economic development model that came into being around 2000. Second, by defining the supply-side structural reform as reforms of industrial structure, regional structure, distribution structure and sectoral structure, previous studies failed to notice that the micro underpinnings of the reforms are enterprises and the transformation of production methods of enterprises is the foundation of structural reforms. Third, as General Secretary Xi Jinping emphasized that innovation should start from China's reality [5], although the existing literature emphasizes the importance of innovation, it does not specifically analyze the key links of innovation in the current stage.

This paper attempts to make up for the deficiencies in previous studies by putting China's economic growth from the perspective of the division of labor in the global production 
network, thereby clarifying the formation process of China's high economic growth and the occurrence mechanism of the New Normal and putting forward feasible approaches to supply-side structural reforms. The paper is structured as follows: the second section explains the formation process of China's high-speed economic growth from 2000 to 2007 based on theoretical logic and empirical evidence; the third section explains the occurrence mechanism behind the shift from high-speed economic growth to the New Normal; the fourth section puts forward possible ways to carry out supply-side structural reform; and the final section draws the conclusion and makes suggestions.

\section{Transformation of the global production system and formation of China's high-speed growth model from 2000 to 2007}

Since the reform and opening-up, China's economic growth has shown distinct features in different development stages (Li, 2018). As shown in Figure 1, from 1978 to 1990, China's economy grew against severe fluctuations, with an average annual growth rate of about $9.2 \%$. In 1990, the total GDP increased by about 3.15 times compared to 1978; from 1990 to 2000, China's economy continued to grow in fluctuations. Throughout the 1990s, China's economy evolved in an inverted " $V$ " shape trajectory, with an average annual GDP growth rate of about $10.4 \%$, and its size in 2000 was about 2.7 times larger than that in 1990 . From 2000 onward, China's economy increasingly turned export-oriented. Along with the global economic growth, from 2000 to 2007, China's economy went upward along the $M$-shape growth trajectory that emerged and unfolded from the 1990s. This period witnessed the fastest and longest-lasting growth of China's economy since 1978. In terms of growth rate and economic aggregate, the year 2000 was a watershed for China's economy. Before 2000, especially in the 1980s, China's economy only enjoyed a rapid growth rate. In the 1990s, the scale effect (China's large absolute economic size) began to come into play. It was in the 21st century that China's economic growth started to enjoy both the effects of growth rate and scale. When we look at China's economy, we cannot just look at its growth rate [6]. Looking at both the economic aggregate and growth rate, we may find that although China's reform and opening-up began in 1978, its rapid economic development did not take off until 1990 and its exponential growth only kicked in 2000 .

China's economic growth is closely related to the process of economic globalization. The ten years from 1991 to 2001 witnessed the birth of today's globalization. Global revolution
Supply-side structural reforms

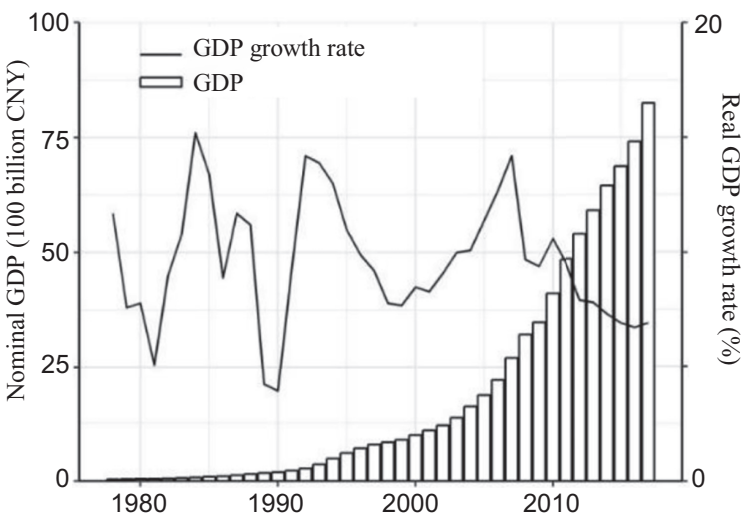

Figure 1.

China's GDP growth from 1978 to 2017

Source(s): Wind 
CPE 3,1

officially came into being in these ten years (Koren, 2015). The world production system underwent a sea change in the 1990s. Production was no longer limited within one country but instead organized and conducted on a regional and global scale (Liu, 2018). Production processes were segmented worldwide by integrated and modular production technologies (Lin, 2009). A global production network characterized by "production fragmentation" has dominated the world since the 1990s. In line with this, the fourth large-scale manufacturing transfer further accelerated in the 1990s, which exerted an important influence on the industrialization process and development conditions of developing countries [7]. Leading enterprises in developed countries let their headquarters to carry out the product conceptual design of the value chain and transferred product manufacturing in the form of modular components production to developing countries where production was fast, inexpensive and of good quality. Although fragmentation of production and segmentation of value chains lowered the bar for developing countries to achieve industrialization by integrating into global production networks, the way they plugged into the global production network and the degree to which they integrated varied from country to country due to varied national realities, and so did the degree to which they benefited from globalization (Liu, 2018). A defining feature of China's rapid development since the late 1990s was that China plugged deeply into the global production network and fully tapped into the international markets. As labor-intensive industries flowed out from developed countries, China made full use of its low-cost labor force and pushed up its exports and export-oriented development, which was an important reason for China's rapid economic growth [8].

In the fourth wave of manufacturing transfer, China found its place in the global production network and managed to attract labor-intensive industries from developed countries, which did not happen by chance. In the early 2000s (2000), China already had conditions such as industrialized production capacity, sufficient labor force, information technology and opening policies, and China's entrance into the WTO in 2001 further nurtured these advantages. These various comparative advantages made China the best destination for industry transfer and production outsourcing. To be specific, first, China bid farewell to the "era of scarcity" in 1998, [9] and gradually formed a huge consumer market. Second, thanks to the reform of popularization of primary education launched in 1982 , by 2000 , the urban labor force had received an average of 10.2 years of education, and the rural labor force had received an average of 7.33 years of education [10]. At the same time, the average wage of manufacturing workers in China was only 1/25 of that of the United States and Japan and 1/27 of Germany (Chen, 2006). Third, by the end of the 20th century, China had already had an independent, complete and coordinated industry system that covered all industrial and mining sectors listed in the International Standard Industrial Classification of all Economic Activities (ISIC) formulated by the United Nations (Dong, 2009). Fourth, to seize the opportunities in the information era (the early 1990s), China's government launched the "Three Golden Projects" (Golden Bridge Project, Golden Card Project and Golden Gate Project) in 1993, and initiated the construction of national information infrastructure in 1997. Statistics from the China Economic Information Network (NEInet) showed that by 2002 the country's telephone penetration rate (including mobile phones) had reached $33.67 \%$, and the internet penetration rate had reached $4.6 \%$. In short, all the conditions were in place for China to receive industry transfer from developed countries at the start of the 21st century.

China's entrance into the WTO in 2001 opened the door to China's deep integration into the global production network. Processing trade was a typical way for China to plug into the global production network and participate in the global labor division. As shown in Figure 2, China's export trade grew moderately throughout the 1980s. Only until the 1990s did China start to enjoy steady growth in foreign trade. Processing trade surpassed general trade to become the dominant form of China's export trade in 1995 and grown rapidly since 2000. During the period from 2000 to 2007, processing trade steadily accounted for around $50 \%$ of 


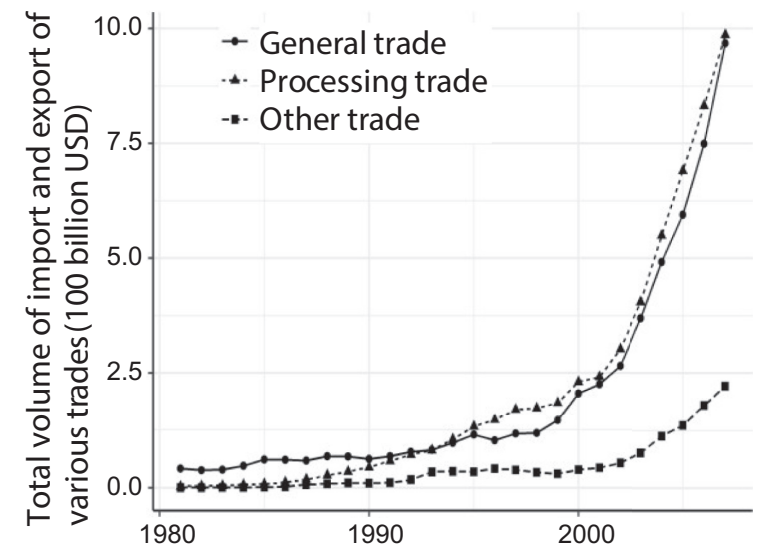

Source(s): General Administration of Customs of China
Supply-side structural reforms

Figure 2.

Structure of China's imports and exports from 1981 to 2007

China's imports and exports. In 2007, it closed at $45.30 \%$, compared with $5.98 \%$ in 1981 . Put into perspective, the total volume of exports grew fivefold from US $\$ 249.2$ billion in 2000 to US $\$ 1,220.4$ billion in 2007 , with an average annual growth rate of $25.58 \%$. From the perspective of fundamental demands, the contribution of exports to China's economic growth in 2007 was as high as $40 \%$ (Li, 2018). The proportion of imports and exports in GDP increased from $39 \%$ in 2000 to $62 \%$ in 2007 , and export expansion was one of the most prominent reasons for this period of rapid growth (Wang, 2018).

The export expansion led by processing trade has increased the rigid demand for the labor force and it became urgent to relax the constraint from the household registration system and encourage rural "migrant workers" to move into cities. With the issuance of policies allowing farmers to move into cities around 1985, a large number of surplus labor force flooded out of rural China and poured into cities, which not only satisfied the demand for labor force for processing trade but also promoted urbanization. The year 1995 was a tipping point for China's urbanization, with an urbanization rate of $29.04 \%$. Since then, China's urbanization rate exceeded $30 \%$ and continued to grow at a faster rate. From 2000 to 2007 , the urbanization rate of China increased from $36.22 \%$ to $45.89 \%$. A natural outgrowth of the rapid urbanization was the high demand for urban housing. In order to take full advantage of the demand for housing to stimulate economic growth, China's government launched the reform of housing commercialization in 1998. As the most important means of living, housing has since landed on the commodity market. Urbanization and housing commercialization have created huge consumer demand and investment space, which in turn has led to the prosperity of the real estate market. As shown in Figure 3, real estate investment fluctuated sharply before the housing reform in 1998. Although it grew rapidly, its scale was not large. After 1998 , in the second year of reform (1999), the real estate investment was close to 500 billion yuan and grew steadily at a fast pace. It had exceeded 2.5 trillion yuan by 2007 , representing a fourfold increase. This point can be seen more clearly from the changes in the sales of real estate. Before 1998, the sales of residential and commercial buildings grew slowly and started to change in 1998. The real estate market was booming from 2000 to 2007.

In sync with urbanization were government investing in infrastructure and corporate investing in enlarging reproduction. As shown in Figure 4, since the 1990s, China's total investment in fixed assets had been mainly driven by urban fixed-asset investment. 1989-1993 and 1999-2003 were two periods of rapid expansion of urban fixed-asset 


\section{CPE 3,1}

98

Figure 3.

Changs in China's real estate investment and consumption from 1986 to 2007

Figure 4.

Changes in fixed-asset investment in China (1981-2017)

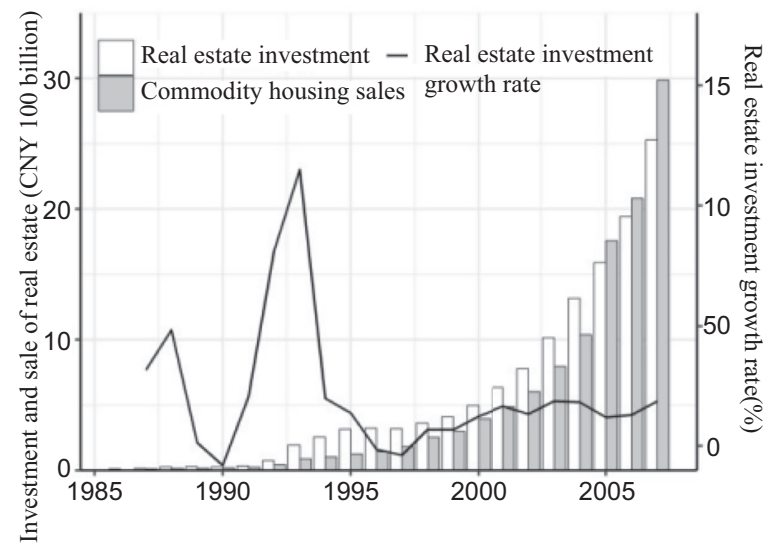

Source(s): Wind

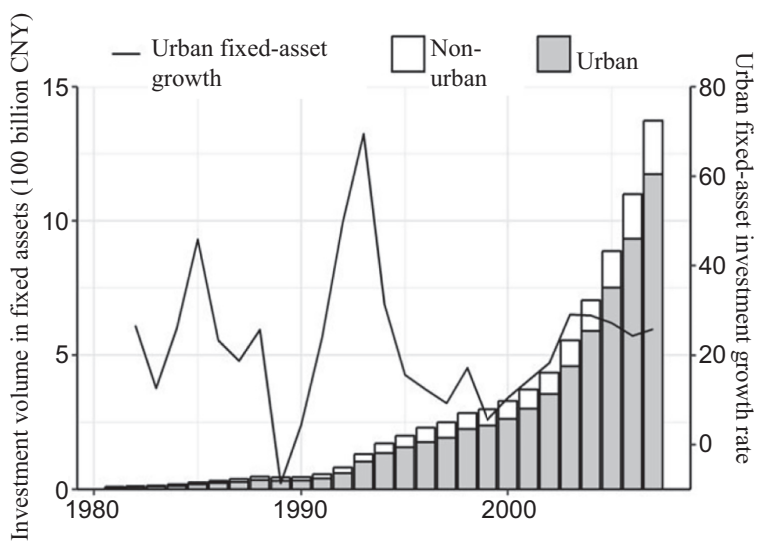

investment. Although the growth rate of urban fixed-asset investment from 1999 to 2003 was not as fast as that from 1989 to 1993, urban fixed-asset investment from 1999 to 2003 had a greater impact on China's economy. The reason was that during the period from 1999 to 2003, urban fixed-asset investment not only increased rapidly, but also had a large size. Looking closely at Figure 4, we can see that a peak in urban fixed-asset investment occurred in 1998, which was a response to the 1998 housing reform.

As the real estate industry and processing trade were at the lower reaches of the industrial chain, a booming real estate market would naturally drive the expansion of production capacity in upstream industries such as metallurgy, chemicals, cement, construction and building materials. Similarly, an increase in orders for processing traders would require the expansion of production capacity, construction of factories and purchase of machinery, thereby stimulating upstream companies that provide energy, resources and raw materials to expand production capacity. This correlative effect of downstream industries on upstream industries is manifested as a "vertical structure" between state-owned and non-state-owned enterprises in China (Li et al., 2014; Wang, 2017). This vertical structure was a product of SOE reform in China in the 1990s. After the SOE reform that "grasped the big and let go of 
the small" in 1995, "China's state-owned and private enterprises formed a complete industrial chain. Most SOEs were at the upstream of the industrial chain and were important players in areas such as basic industries and heavy manufacturing. Private enterprises played an increasingly important role in providing manufacturing products, especially final consumer goods. These two kinds of enterprises were highly complementary, cooperative, and mutually supportive" [11]. This vertical structure between SOEs and private enterprises made private enterprises sensitive to changes in demand conditions. From 2000 to 2007, China's domestic and external demands were strong and stable. The strong demand led to the prosperity of downstream enterprises, which were mainly private enterprises. The prosperity of downstream enterprises then fueled the development of upstream enterprises, of which mainly SOEs, by the correlative effect. The net asset profit margin of SOEs jumped from $5.7 \%$ to $12.1 \%$ from 2001 to 2007 , and the sales profit margin increased from $3.7 \%$ to $9 \%$. The total profit of all state-owned industrial enterprises nationwide in 2007 reached 979 billion yuan, more than three times that of 2003 (308 billion yuan). Admittedly, this round of high growth of profits of SOEs from 2000 to 2007 was not only attributed to the strong external demand that stimulated the vigorous development of downstream industries but also to the monopoly position of the SOEs in key industries and the support of government fiscal and taxation policies they enjoyed (Liu and Shi, 2011; Yang, 2014; Wang, 2017).

To sum up the characteristics of China's rapid economic growth from 2000 to 2007, with China's entry into the WTO in 2001, Chinese enterprises deeply integrated into the global production network in the form of processing trade that produced modular components, forming an outward-oriented growth model co-driven by investment and export. This model was the result of a combination of domestic and external demands. Domestic demand was manifested by urbanization and the booming real estate market, while external demand was reflected by export expansion. Domestic and external demands and investment strengthened each other, driving the prosperity of downstream industries. Downstream industries, in turn, stimulated the expansion of upstream industries along the industrial chain, bringing generous profits to SOEs and propelling the rapid economic growth at the beginning of the 21st century.

\section{The occurrence mechanism of the economic shift from high-speed growth to the new normal}

From 2000 to 2007, just one year before the outbreak of the financial crisis, Chinese enterprises deeply integrated into the global production network by producing and processing modular components, which supported the high-speed economic growth. After the financial crisis, China's economic growth slowed down from a high speed to a low-tomedium one. Admittedly, the "four trillion yuan" stimulus package enabled China to maintain a growth rate of about 10\% from 2008 to 2011. After 2011, however, aggregate demand management policies became less and less effective. As a result, China's economic growth rate fell to $8 \%$, and then below $7 \%$ and beyond (Lo, 2018). General Secretary Xi Jinping defined this downward trend as the "New Normal." The economy is intrinsically an evolving continuum. Its continuity reminded us that China's entry into the New Normal was due to the change in the socioeconomic conditions that fueled the high growth of economy from 2000 to 2007. That is, the demand and supply that benefited China as its enterprises plugged into the global production network bumped into constraints.

\subsection{Overcapacity due to a decline in external demand}

As the 2008 financial crisis swept the globe, Western economies went out of the golden growth period and stepped into a period of profound adjustment. Effective demand went 
CPE 3,1

100

down, and re-industrialization and the import substitution effect that drew back industries into their own countries ticked up, which directly led to a slowdown in the growth of China's external demand. At the same time, significant changes took place in China's socioeconomic conditions. The most significant change was the rapid rise in the cost of production factors such as labor force in China. Emerging economies such as ASEAN countries and other developing countries seized the opportunity and jumped into the international division of labor with their comparative advantages of low-cost labor force and abundant natural resources. Industries and orders were prone to escaping to China's neighboring countries, which resulted in increased export competition for China [12]. As a result, China's economy experienced a rapid decline after a period of rapid growth from 2001 to 2007 . As shown in Figure 5, China's export growth rate dropped from $25.95 \%$ in 2007 to $17.23 \%$ in 2008 and fell further by $16 \%$ from 2008 to 2009 . To curb the adverse impact of the financial crisis, China's government rolled out a "four trillion yuan" stimulus package in November 2008. The package boosted the demand and reinvigorated the economy in the short term. Exports bottomed out in 2009 and rose against adversity from 2009 to 2010. From 2010 onwards, export growth fell again until 2015. Reduced exports led to shrinking investment and overcapacity in processing trade companies. This round of overcapacity was different in that it was global and sustained (Sun and Wen, 2017). The shrinking production of downstream light industries was "transmitted" to the upstream industries, leading to the overcapacity of the heavy chemical industries in the upstream. Moreover, overcapacity was even more severe in heavy chemical industries, as their substantial investment in fixed assets made it harder to cut down on surplus capacity. In 2017, China's coal mining and washing industries, and ferrous metal smelting and rolling industries suffered low capacity utilization rates, $68.2 \%$ and $75.8 \%$, respectively (Xie, 2018). Most enterprises with severe overcapacity problems were SOEs, which was largely due to the vertical structure of distribution of SOEs and private enterprises along the industrial chain.

\subsection{Systematic changes in China's income distribution and demand structure}

The development model where China integrated into the global production network by processing and producing modular components not only boosted exports and GDP, but also created a large number of jobs in China and put more money into workers' pockets. In short, China's golden period of economic growth from 2000 to 2007 was accompanied by a virtuous cycle of production expansion, income increase and consumption growth. Statistics showed that consistent with the GDP growth trajectory, the household income per Capita in urban

Figure 5.

Changes in China's imports and exports from 2008 to 2017

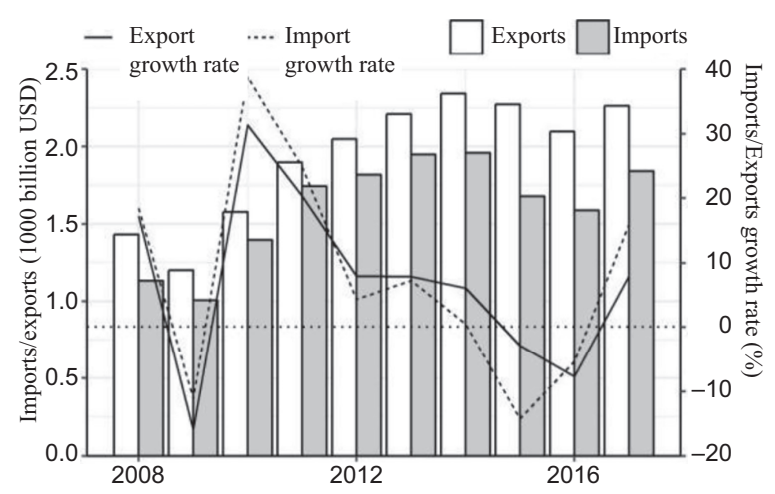

Source(s): National Statistical Yearbook 
and rural areas of China also took off from the 1990s. As shown in Figure 6, from 1990 to 2015, the annual household income per Capita for urban and rural households in China experienced roughly three periods of rapid growth, namely 1991-1994, 2000-2007 and 2009-2011.

After rapid income growth from 1991 to 1994, China's stable internal demand and the unified domestic market basically came into existence in 2000. The consumption demand has the obvious character of following suit and the demand for low-priced standardized products was huge. This market demand structure coincided with mass production, supporting the domestic demand that led to China's economic prosperity in 2000-2007. Although China's economy suffered at the end of 2007 from the impact of the financial crisis, as shown in Figure 6 , the per-capita income of urban and rural households maintained an upward trend from 2009 to 2011 and did not decline until 2012. The household income per capita of urban and rural households went through three rounds of growth in 1991 to 1994, 2000 to 2007 and 2009 to 2011 and the living standards of Chinese residents improved significantly. As of 2017, China's Engel coefficient dropped to $29.3 \%$ and for the first time, fell into the range between $20 \%$ and $30 \%$, the rich range defined by the United Nations. China was home to up to $36 \%$ of the world's 1.1 billion middle-class population (Xie, 2018). For these wealthy middle-incomers and higher-incomers, low-priced standardized products were far from enough to meet their diverse and personalized demands. Insufficient supply capacity caused a large amount of demand spillover and serious outflow of consumption power, which was particularly evident in luxury consumption. The proportion of overseas luxury consumption in China's total luxury consumption increased year after year, climbing from $56 \%$ in 2009 to $72 \%$ in 2015 and reaching as high as $76 \%$ in 2016 [13]. The serious outflow of high-end consumer demand represented by luxury goods indicated that China was not short of demand. The truth was that consumption demand in China changed and was left unmet because the quality and postsale service of products provided in China failed to keep up.

As China integrated into the global production network, the income of urban and rural households went through three rounds of growth in 1991-1994, 2000-2007 and 2009-2011. China's income distribution structure also changed. As shown in Figure 7, since 2000, the overall urban-rural income gap in terms of household disposable income per Capita kept widening. Although the relative income gap between urban and rural areas began to narrow after 2009, the absolute per-capita income gap between urban and rural areas was still expanding year by year, as shown in Figure 6. In 2016, urban residents had a per-capita income 2.72 times higher than rural residents. 2008 was the year with the largest income gap,
Supply-side structural reforms

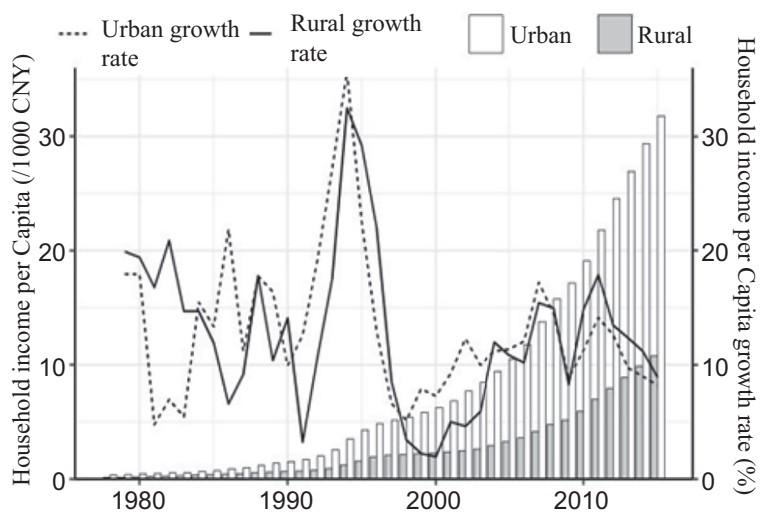

Figure 6.

Changes in annual household income per capita for urban and rural households in

China from 1978 to 2015

Source(s): Wind 
CPE

3,1

\section{2}

Figure 7.

Changs in China's overall and urban-rural income inequality from 1978 to 2017

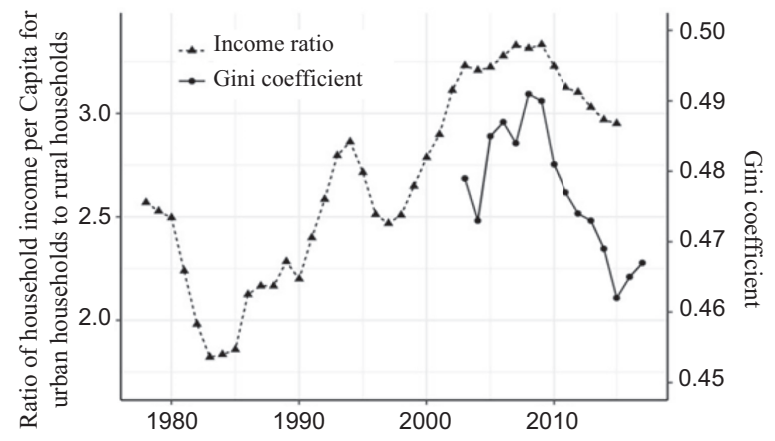

Source(s): Wind

as the Gini coefficient reached a peak of 0.491 and then was followed by a seven-year decline. In 2015, China's Gini coefficient dropped to the lowest point (0.462) since the reform and opening-up, but it was still above the international warning line (0.4) and rose again after 2015. Changes in income distribution and differences in income growth led to greater differences in the lifestyles of groups in different strata and regions in China. At the same time, opening-up intensified market competition between Chinese products and products of foreign brands. These two factors combined to cause a systematic change in China's market structure and demand structure. The unified market shifted to a diversified market that kept splintering into segment markets. The entire market was in a state of dynamic and incomplete competition. China's unified demand for standardized products became history, and the domestic demand structure evolved in the direction of diversity, multi-variety and personalization. However, this shift did not eliminate the demand for standardized products. On the contrary, due to the sheer population size, complex geographical distribution and income disparity, many people in China still lived in poverty. Unlike middle-incomers and higher-incomers who prefer diversified and personalized products, they still favored low-cost standardized products. That is why China has a multi-layered dynamic demand structure in which standardized demands and personalized demands coexist, which is the most basic fact of China's current domestic market demand structure.

\subsection{Difficulty in changing production methods leading to declined profitability and insufficient productive investment}

The mass production model has interchangeable parts as the technical support and is characterized by assembly-line production, which was introduced into China in the 1980s under the background of emphasizing introducing advanced technology from abroad $(\mathrm{Lu}, 2006)$. Any manufacturing model is essentially driven by market and social demand, and each manufacturing revolution is triggered by new market and economic situations and emerging social demand driven by consumers (Koren, 2015). In short, the way companies produce must match the country's market and social demand structure. The mass production system has very strong production capacity, but most of its capacity caters to low-end, lowquality and low-price standardized demands, which was in line with China's investment- and export-led demand structure from 2000 to 2007 and thus led to the golden period of China's economic growth from 2000 to the outbreak of the financial crisis. However, the outbreak of the financial crisis and changes in the domestic demand structure posed severe challenges to the mass-production model that was widely adopted by Chinese enterprises. First, the external environment that the mass-production model relied on changed. The demand was no 
longer stable, the market was no longer unified, and the product life cycle was getting shorter. Second, the special-purpose machine that the mass-production model relied on fulfilled only one function and was usually designed for only one product and intended for selling low-cost and standardized products to a unified market (Pine, 2000). It was unable to meet diversified and personalized demands. Finally, the cost advantage that the mass-production model hinged on was declining sharply. According to Boston Consulting (BCG, 2014), the current average cost of manufacturing in China was only about $5 \%$ lower than that in the United States.

As previously analyzed, after the rapid growth from 2000 to 2007, major changes took place in the demand structure and consumption patterns of Chinese residents. The era of consumer demand following suit basically came to an end while personalized and diversified consumption gradually took center stage. Stimulating demand through innovative supply significantly gained in importance [14]. Facing slowing international market growth and updating domestic consumption structure, the mass-production model seemed to be out of place. Solving the structural problem of mismatched supply and demand requires that companies change their mass-production model and make their supply structures more adaptive and responsive to changes in demand. However, it took efforts for enterprises to change their production methods. On the one hand, the sunk costs of mass-production models were huge, and it would cost the company a fortune to change their production methods. On the other hand, China's independent innovation capacity was insufficient, as China heavily relied on the introduction and imitation of foreign technologies starting from the 1990s. The supply system capable of responding flexibly to changes in demand is centered on key component technologies, and the innovation of key components hinges on the company's independent innovation capabilities. Therefore, the transformation of Chinese enterprises' production methods was bound to be a long process.

It was because of the mismatch between the dominant mass-production model and the socioeconomic conditions and demand structure after the financial crisis, coupled with the difficulty in changing production methods, that the downward trend in the profit margin of China's manufacturing was inevitable. The declining trend of China's manufacturing profit margin had revealed itself in the early 1990s because of insufficient technological innovation (Zhou, 2015). Entering the year 2000, Chinese enterprises integrated into the global production network by producing and processing modular components, therefore, circumventing the limitation of insufficient innovation to a certain extent and easing the downward pressure on profitability, as was evidenced by the two " $V$ "-shape transformations from 2000 to 2007 (Xie and Li, 2016). After the financial crisis, the external demand effect of the huge international market no longer existed, and the diversified and personalized demands of the domestic market were left unmet. Therefore, the profit margin fell again at the end of 2007 and dropped to $13.6 \%$ in 2011 and $11.2 \%$ in 2014 (Zou and Liu, 2017). There was no obvious sign indicating that the fall would stop.

A natural outgrowth of falling profitability was a decline in investment. After the financial crisis, China's manufacturing industry was sluggish. By 2015, the growth rate of manufacturing investment was close to zero and it dropped to the negative field in 20162017. In order to stimulate manufacturing investment and revitalize the real economy, China rolled out a large-scale stimulus package after the financial crisis. The result, as shown in Figure 8, was that the national growth rate of fixed investment experienced a " $Z$ '-shape trend from 2008 to 2011. However, starting in 2011, the growth rate of social fixed-asset investment plummeted and as of 2017 it had fallen to $5.73 \%$, which showed that demand management policies failed to reverse the fall in manufacturing investment. The reason why the policy of demand management did not work as expected was that the root cause of the lack of investment willingness of manufacturing enterprises was the low profit margin of the manufacturing industry, and the source of the profit margin decline was on the supply side, that is, the production methods of enterprises failed to change. 
CPE

3,1

\section{4}

Figure 8.

Changes in China's fixed-asset investment from 2007 to 2017

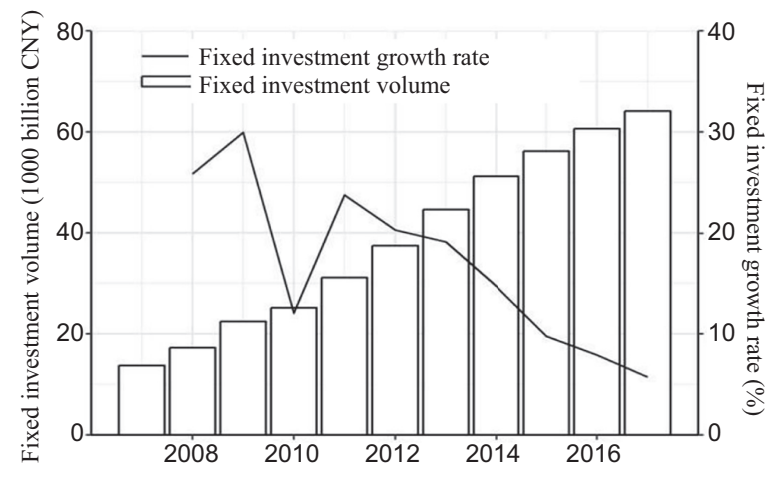

Source(s): Wind

Another consequence of the decline in manufacturing profit margins was the shift from the real economy to the virtual economy. As shown in Figure 9, the share of China's manufacturing investment declined rapidly from 2008 to 2009, from 66.41 to $37.86 \%$, while real estate investment in the same period did not decline significantly. The difference between the trend of manufacturing investment and real estate investment was most obvious from 2009 to 2011, and real estate investment showed a clear upward trend from 2009 to 2010. One possible explanation was that most of the bailouts from the government and the central bank went to real estate rather than manufacturing. By looking at the government's four trillion yuan stimulus package and the central bank's ten trillion yuan credit, we would find that the intersection of fiscal policies and real estate was the "affordable housing project," which, however, only accounted for $7 \%$ of the 4 trillion yuan [15]. In contrast, the size of credit funds brought by monetary easing was larger and it was these funds that stimulated the real estate market.

In order to cope with the decline in profitability, many companies chose to "go financial" instead of innovating and changing production methods. They invested in the financial sector instead of production, which in turn brought down productive investment in manufacturing (Zhang and Zhang, 2016). "Going financial" would undoubtedly bring considerable profits to enterprises in the short term, but this came at the expense of long-term development. If China wants to fulfill the transition from a large manufacturing country to a strong manufacturing country, it must stop the real economy enterprises from going

Figure 9.

China's investment in manufacturing and real estate from 2007 to 2017

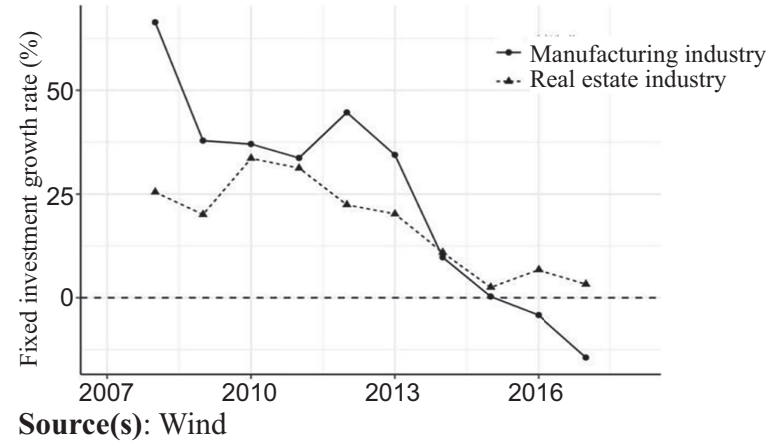


financial. To do that, macro-control on the part of the government was indispensable. In the end, however, it all boiled down to the transformation of production methods on the part of enterprises. Only by changing the mass production model that was incompatible with the current socioeconomic and demand structure, would investment in expanding reproduction become profitable again. Only when the manufacturing industry itself was profitable would enterprises stop turning towards the financial market. Changing the production methods of enterprises was not only the key to revitalizing China's manufacturing industry but also an urgent requirement for enhancing the competitiveness of China's manufacturing industry in the international arena. In the past ten years, China is not only losing its low production cost advantage but also losing its advantage in owning a complete industry chain (Cheng, 2018). The duality of rising production costs and weakening industry chain advantage has resulted in a large number of foreign companies being relocated from China to countries and regions with lower manufacturing costs such as their home countries or Southeast Asia. As shown in Figure 10, since 2001, the number of foreign companies above designated size in China reached a peak of 76,249 in 2009, and the proportion of industrial enterprises above designated size peaked at $20.72 \%$ in 2005 . Since 2011 , the absolute number of foreign companies and the proportion of industrial enterprises have fallen sharply. In 2017, the sheer number fell to 49,911 , and the proportion also dropped to $12.96 \%$. Since 2000 , foreign companies have been the main force in China's exports. In 2011, the proportion of net exports of foreign companies to China's total net exports was as high as $84 \%$. As foreign companies move out of China, the role of exports in driving China's economic growth will be greatly weakened.

To sum up, the financial crisis in 2008 broke the investment- and export-driven growth model formed in China since 2000. As the external demand shrank, China's widely applied mass-production methods introduced in the 1990s were unable to satisfy the individualized, diversified and advanced demands in segment markets, which led to widespread overcapacity. When mass-production methods failed to change, the combination of rising production costs and weakening industry chain advantage brought down manufacturing profit margins and led to insufficient domestic productive investment and foreign capital outflow. It was the combination of these factors that brought China from a high-speed growth track to the New Normal.

\section{Approaches to supply-side structural reforms}

To achieve high-quality development in the New Normal, the supply-side structural reforms should be conducted with long-term consideration with the goal of unleashing long-term

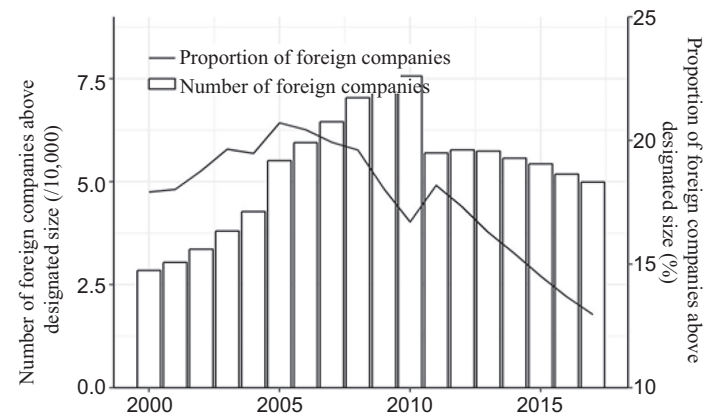

Source(s): General Administration of Customs of China
Supply-side structural reforms

Figure 10 .

Number and proportion of foreign companies in China from 2000 to 2017 
CPE

3,1

development potential. It is not only about addressing short-term structural overcapacity and reducing ineffective and low-end supply but also about expanding effective middle- and highend supplies, enhancing the adaptiveness and responsiveness of supply to changes in demand and ensuring the capital investment efficiency and the sound development of the capital cycle. Based on China's reality, considering the inherent contradictions of the global production network, and practices of developed countries in solving overcapacity and innovating production methods, the authors would like to propose the following three approaches to supply-side structural reforms.

\subsection{Rural revitalization for absorbing excess capacity and improving resource utilization efficiency}

David Harvey's (1978) capital circulation theory shows that inconsistencies between individual rationality and group rationality will result in total corporate investment exceeding the normal demands of socialized mass production and therefore excessive accumulation in direct production sectors. In order to address product surplus, labor excess, capital (machine) idling and profitability decline caused by excessive accumulation, enterprises can transfer and inject excess capital into a new geographic space to form fixed assets and consumption funds, that is, a built environment for production and consumption; or invest excess capital in science and technology or utilized the excess capital as social spending on labor reproduction. The built environment for production and consumption can "not provide any production materials and living materials for a long period of one year or more, and provide no useful effects, but will take away labor and production materials from the total annual production" (Marx, 2004). On this basis, a new round of capital cycle is formed. Governments invest surplus capital in the form of public expenditure in projects that benefit the country and the people with long-term returns and delay capital re-circulation. In this way, capital excess is repaired temporally and spatially.

According to China's reality, in the current context of structural overcapacity, the industries and enterprises with severe overcapacity should be dealt with first. At present, the problem of excess capacity in upstream industries and enterprises is prominent. There is a lot of excess capacity and capital stranded in the first-level capital cycle of the direct production process. Through the merger and reorganization of related enterprises, internal optimization and business integration, upstream enterprises will be able to integrate quality resources, phase out backward production capacity and bring resources into new geographic space so that they can form new production capacity in the secondary capital cycle. The question is where to establish the built environment for production and consumption. After years of urbanization, cities in the eastern, central and western China have all been equipped with sound infrastructure and it is hard to find undeveloped areas for further infrastructure investment. In Harvey's words, the capital's spatial fixes in midwestern cities are nearing the quota. In this case, if we insist on developing the built environment for production and consumption in cities, we have to renovate or rebuild old infrastructure. The practice of spatial reconstruction for construction's sake is essentially the destruction of productivity and it goes against the high-quality development philosophy advocated by General Secretary $\mathrm{Xi}$ Jinping. Therefore, we should turn our eyes to the rural areas.

For a long time, migrant workers in eastern China have been mainly employed at home or near home, while those in central China have mainly been employed outside their regions. By using the central rural area as a new space for capital fixes, China will not only enhance the long-term development capacity of its central area, narrow the gap between its inland and eastern coastal areas, but also draw migrant workers back to central China. In recent years, as China's industry structure shifts from low-end labor-intensive industries to mid- and highend smart manufacturing and service industries, the capacity of cities to absorb surplus rural 
labor has weakened and the return of migrant workers has become an inevitable trend. The limited construction space in cities and the tendency of migrant workers to return indicate that rural areas are currently the best place in China to absorb excess capacity through capital fixes. Looking back on the evolution of China's economy, we can find that whenever there is a surplus of labor or capacity, the rural areas will absorb them effectively without fail. Whether in the late 1950s and early 1960s when the Soviet Union's divestment forced China's surplus labor force to the countryside or in 1997-1998 and 2007-2008 when the East Asian financial crisis and the US financial crisis drove excess capacity to the rural areas, China's rural areas were always able to cushion the blow from economic fluctuations by absorbing surplus labor force and excess capacity. Since the New Normal, China has once again been troubled by overcapacity. "Bringing capital to the countryside" is still a possible solution to this round of overcapacity. People in rural China have enjoyed much better infrastructure, residential environment and livelihood since China proposed to "construct a new socialist countryside" in 2004. However, "indoor tidy, outdoor dirty" is still the case in rural China, the main cause of which is the negligence in constructing underground pipe networks. Therefore, the construction of underground pipe networks in rural areas, in a realistic sense, should be an integral part of the "rural revitalization" strategy. In theory, in order to delay overaccumulation within the newly opened capital cycle, capital fixes in a specific area should follow three principles: first, public expenditure projects must be able to absorb excess capacity and ensure full employment for the returning migrant workers; second, products from capital fixes do not need to trade on the market and the capacity will not be expanded; third, capital fixes should benefit ecological protection and sustainable development. The construction of rural underground pipe networks obviously complies with these three principles.

The underground pipe network construction in rural areas will not only promote the "rural revitalization" but also channel China's infrastructure investment to the right place. Infrastructure investment is an effective means to stimulate economic growth and it works worldwide, not just in China. As we face sluggish external demands, it is even more important for China to give full play to infrastructure investment. However, according to the statistical analysis by $\mathrm{Hu}$ (2018), since the beginning of 2018, China's infrastructure investment has fallen sharply. It was not until October 2018 that China's infrastructure investment began to pick up, increasing by 8.1\% year-on-year in October and therefore ending its quarter-long negative growth. The reasons for dwindling infrastructure investment are: first, China's government is facing more headwind when carrying out de-leveraging and structural reforms and therefore has to cut down on infrastructure investment; second, there is a lack of high-quality projects to absorb capital. In fact, the dilemma of "de-leveraging government debt" and "increasing infrastructure investment" is not insurmountable. China's total M2 in 2017 reached about 170 trillion yuan, which was 1.84 times that of the United States. Considering the additional liquidity released in 2019, we may find that China's economic system is flooded with currency and capital and badly in need of channels to transfer surplus capital. Admittedly, excess capital and excess capacity can be exported to the "Belt and Road" countries. That, however, requires stable global demand and is essentially subject to external demand (Zhang, 2018). In contrast, a government-led rural infrastructure project funded by excess capital is much more resilient to the change in external demand and will be able to boost infrastructure investment without raising governmental debts. Therefore, the strategies of "clean water and green mountains" and "beautiful countryside" are more reliable for absorbing excess capacity and capital.

The construction of underground pipe networks in rural areas is a major systematic project that is both time-consuming and cash-burning. It requires deliberation and design in all aspects of investment and construction. First of all, the rural areas in western China are sparsely populated with highly decentralized infrastructure. Therefore, western China is not
Supply-side structural reforms 
CPE 3,1

108

an ideal place for intensive investment and construction. A stable move here is to pilot in the central rural area and then promote best practices. Second, the rural areas in central China lack the ability to make huge investments, so governments should lead the investment and encourage private investment in large-scale public expenditure projects. This will not only ease the financing constraints over underground pipe construction projects, but also motivate private investment. Lastly, although it is only natural for state-owned enterprises to carry out the construction projects, given that underground pipes are public goods, private enterprises should not be excluded. The supply of public goods, such as underground pipe networks, can be jointly provided by state-owned enterprises and private enterprises. By so doing, we will create a virtuous cycle of production, distribution and consumption in rural areas as we improve the built production and consumption environments in rural central China.

\subsection{Construction of key component development platform for key component innovation}

Since 2000, Chinese enterprises have plugged into the global production network by producing modular components and turned China into a "world factory" by virtue of their comparative advantages in producing modular components. In the division of labor in the global production network, the profits derived from the production of modular components are quite meager. China, with its sheer size as the "World Factory," achieved economic prosperity from 2000 to 2007 through quantity-driven industrialization. But after all, this was a low-end industrialization model that solved the quality problem with a quantitative method (Unger, 2018). Moreover, the decline in China's overall competitiveness in global manufacturing also shows that the way China integrates into the global production network by mass producing modular components is out of place. If we want to revive the competitiveness of our manufacturing industry in the international market, we must change the way China plugs into the global production network. As General Secretary Xi Jinping said, it is necessary to work hard from the supply side to find China's position in the world supply market [16]. The technological foundation of modern manufacturing has undergone a fundamental change. To accommodate the changes in market demand structure, enterprises have to conduct a systematic overhaul over all links or relevant departments of the entire production process. The core of this systematic change is the innovation of key components in product development. Such innovations will change product mixes, leaving modular component manufacturers no choice but to evolve and accommodate the changes, which means that key component innovation occupies a decisive strategic position in the global manufacturing competition. Whoever gains the first-mover advantage in key component innovation will have a competitive edge in global manufacturing. Therefore, the transition from a modular component supplier to a leading key component innovator is an inevitable choice for China to transform from a big manufacturer to a strong manufacturer and to move into a high-quality development track.

However, at present, there is only a small proportion of China-made key components in China's high-tech products. China's import of precision instruments, aerospace equipment, automobiles and parts and other high-end manufactured products is greater than its export. In 2017, China's processing trade exports accounted for 34\% of the total exports and processing with imported materials accounted for $90 \%$ of the total processing trade exports (Xie, 2018). Due to insufficient innovation of key components, China's production of high-tech products is severely subject to developed countries such as the United States. Once the supply of key components stops, it is difficult for China's companies to go on with their production. To improve China's competitiveness in the global manufacturing competition and reverse the decline in manufacturing profit margins, we must make breakthroughs in key component innovations, change the way Chinese enterprises integrate into the global production network and move from producing modular components to innovating key components and 
designing and developing product standards [17]. Building a high-end manufacturing system driven by the innovation of key components is a complex systematic project. Governments, enterprises, universities and research institutes have a shared responsibility for building a national manufacturing innovation network, but have differentiated roles to play in different parts of the network. In this regard, China can learn from the innovation strategy developed by the United States to maintain their competitiveness of their manufacturing industry in the new era. ${ }^{\text {(i) }}$ China's government should:

(1) Continue to enhance investment in technical infrastructure and drive private investment with public investment to fully mobilize social capital to invest in manufacturing.

(2) Strengthen the protection of intellectual property rights, which can not only stimulate the enthusiasm of scientists and entrepreneurs to engage in manufacturing R\&D and investment, but also help cultivate a "new technology market," that is, to make new technologies sellable.

(3) Optimize the top-level design of the technological innovation system and make good use of China's institutional advantages in S\&T management, so as to help companies transform the basic research to scientific and technological achievements and further commercialize them Universities and research institutes should pay special attention to STEM education (science, technology, engineering and mathematics), and produce a large number of R\&D talents and high-quality technical workers while advancing basic research.

In the new era, innovation should be geared to the national economy, which means enterprises are the main innovators and the innovation of key components ultimately rests on the shoulders of enterprises. Product development is the central link of technological innovation and product development platforms are the vehicle for product development. Therefore, to achieve independent innovation of key components, enterprises must first develop their own product platforms $(\mathrm{Lu}, 2018)$. Although development platforms will help companies to gain the initiative in key component innovation and obtain their autonomy in technology trajectory, which is only half the story. Large-scale market application is required to make China's proprietary technology trajectory a dominant standard for global manufacturing (Lu, 2006). Modern manufacturing technology often has a network effect, that is, the value of connecting to a network increases according to the number of others using it (Shapiro and Varian, 2000). It is the network effect that puts the design standard of the technology trajectory at the center of the global competition - under the positive feedback of the network economy, only one of the various technology trajectories wins out in the competition and becomes the dominant design standard, while others fade out of the market, that is, winner takes all (Shapiro and Varian, 2000). Fortunately, China has a huge domestic market. With the support of the government, China should make full use of its sheer market size and break through the threshold of user size, so as to form a positive network feedback effect. Only in this way can China's standards for key component and product development win out in the global competition.

\subsection{Construction of domestic enterprise production network for adapting to the dynamic and diversified demands}

After experiencing rapid growth from 2000 to 2007, China put an end to its era of consumption following suit and gave center stage to personalized and diversified consumption. It is increasingly important to ensure product quality and safety, and stimulate demand through innovative supply in China [18]. In the face of declining profit

Supply-side structural reforms 
CPE 3,1

margins and mounting overcapacity, enterprises are reluctant to invest in the real economy. Admittedly, measures such as "cost reduction," "tax reduction" and "financing support to private enterprises" can encourage investment. However, if the current mass production model is not to change, newly produced products will once again suffer poor sales and oversupply, as they will not be able to meet diversified demands. Therefore, the fundamental solution to overcapacity lies in innovating production methods and enhancing the adaptiveness and responsiveness of supply structure to changes in demand [19]. From the perspective of the evolution of global production models, mass production is compatible with standardized demands and mass customization is suitable for personalized demands. Neither mass production nor mass customization can meet China's dynamic demand structure where standardized demands and personalized demands coexist. Therefore, Chinese enterprises will need a new production model that is compatible with its special domestic demands. The experience of developed countries tells us that only by building a flexible and specialized enterprise network can companies be more responsive to the diversified demands, to the everchanging market and to the frequent technological updates. Faced with the ever-changing market and technological innovation, the best tactic for leading companies is to break the vertical integration by focusing on core links and outsourcing non-core links and to bring components and equipment suppliers at different levels into the open product framework for establishing a long-term consortium (Xie, 2006). This consortium exists in the form of a production network. Leading companies are at the core of the network, so they can also be called core enterprises while component and equipment suppliers are at the periphery, so they can also be called peripheral companies.

The first obstacle to building a domestic production network is that many Chinese enterprises are organized in a multi-divisional form (or "vertically integrated form" in China's term) and their businesses proceed in a fragmented way along the "automated assembly lines," in accordance with Adam Smith's "division of labor." This model certainly represents the forefront of the corporate development model of the 20th century, but it is outdated in the 21 st century. In the 21st century, customers have the upper hand, competition is getting intensive and change is commonplace, which is a completely different story than the 20th century (Hammer and Champy, 2007). Therefore, enterprises must face the reality of the coexistence of standardized and differentiated demands in China. They should re-engineer their business processes to cut costs and save time, and simplify business procedures and compress organizational hierarchy to flatten their organizational structure. Core enterprises should establish product design standards, focus on key component innovation and integrate various businesses including product design, raw material supply, production, wholesaling, marketing and final product delivery. By establishing an integrated, innovative and flexible production model, enterprises can calmly respond to changes in demand and the resulting market instability and uncertainty. In this production model, main innovators are not a single scientist or engineer, but all employees of an enterprise, and technical innovation is no longer a one-way series connection but a closed-loop parallel connection - product development and process development move forward neck and neck; research and production come hand in hand, which improves the efficiency of not only enterprise operation but also continuous product improvement. In the production network, in order to occupy a better position, component and module suppliers at different levels will keep updating their manufacturing process parameters of modules. With additional competitive pressure from outside the network, members of the production network will all be committed to the continuous innovation of products, techniques, designs and processes. Since module suppliers or the peripheral enterprises still adopt mass-production model, they will be able to produce products in large quantities in accordance with the requirements of core companies. In this way, the production network that combines the integrated, innovative and flexible production model of core enterprises and the mass production model of peripheral 
enterprises will bring mass production and product innovation together in an organic manner, thereby meeting both standardized and personalized demands of our people.

Building a production network to increase the responsiveness of a supply system to changes in demand is not only feasible in theory, but also operable in light of China's reality and here are the reasons. First, China has a vast territory and unbalanced regional development. Although China has rolled out regional re-balancing strategies such as "Great Western Development," "the Revitalization of old industrial base of Northeast China," and "the Rise of Central China," with an aim to narrow regional disparities, there are still gradient economic imbalances among eastern, middle and western China (Sun and Yao, 2014; Wang et al., 2014). Imbalanced regional development provides space for constructing domestic production networks. The combination of standardized demands in underdeveloped central and western China and personalized demands in well-developed eastern China urgently calls for a new supply system that meets the said demands at the same time. The domestic production network can be the urgently-sought-for supply system. Second, there is still a development gap between urban and rural China (Liu and Cai, 2018). The yawning absolute income disparity between urban and rural areas leads to demand inconsistency: a great demand for standardized products unmet among the rural population and an increasingly keener interest in personalized products among urbanites. The multi-layered and diversified urban-rural demand structure provides demand conditions for the construction of domestic production networks. The construction of domestic production networks can also be carried out in combination with the mixed-ownership reform of state-owned enterprises. Whether SOEs or private enterprises take the lead, the construction of production networks will bring them into a benign interaction that is cooperative and competitive at the same time.

\section{Conclusion and implications}

Since 2000 China has been expanding into the global markets faster than ever before. It integrated into the global manufacturing network by producing modular components and the resulting investment- and export-led pattern of economic growth underpinned the rapid growth between 2000 and 2007. However, the 2008 financial crisis disrupted this pattern of economic growth. The combined impact of a drop in external demand and failures in massproduction model among Chinese enterprises led to widespread overcapacity (Sun and Wen, 2017; Zhang and Jiang, 2017). Since General Secretary Xi Jinping proposed strengthening the supply-side structural reform in 2015, the tasks to address overcapacity, reduce inventory, deleverage, lower costs and bolster areas of weakness have achieved remarkable results. The inefficient and redundant capacity was effectively reduced and eliminated. China cut 115 million tons of steel capacity and over 400 million tons of coal capacity between 2016 and 2017. Benefiting from the backward capacity being replaced by the competitive capacity between 2016 and 2017, in the first three-quarters of 2018, China's output of pig iron, crude steel and steel increased by $1.19,6.07$ and $7.21 \%$ respectively and the competitive capacity in the coal industry further increased and was steadily released. Large and modern coal mines have been the main engines for China's coal production. The supply quality and efficiency of the coal industry improved significantly. The capacity utilization rate experienced a remarkable increase from $72.9 \%$ in the second quarter of 2016 to $78 \%$ in the fourth quarter of 2017. In the third quarter of 2018, the capacity utilization rate of China's overall industrial sector reached $76.6 \%$. The new engines for economic growth gradually came into being. From 2015 to 2017, the New Economic Driver Index increased by 23.5, 26.9 and 34.1\% over the previous year, respectively. As of the end of November 2018, the added value of China's high-tech manufacturing and equipment manufacturing industries grew by 11.8 and $8.3 \%$ respectively; greater efforts were made to cut taxes and fees and the costs of institutional transactions continued to decrease. In the first ten months of 2018 , the costs for
Supply-side structural reforms 
CPE 3,1 per-hundred-yuan turnover of principal activities of the industrial enterprises above designated size (enterprises with annual sales revenue over 20 million yuan) stood at 84.27 yuan, a decrease of 0.25 yuan year-on-year. According to estimates, it was expected to reduce costs by more than 1.1 trillion yuan for enterprises throughout the year [20].

However, we "should notice that at present China's economy faces problems: Its supply system fails to adapt to the structural changes in demands, and a virtuous circle in the economy is hard to achieve" [21]. The key to solve these problems fundamentally is to change the mass-manufacturing model currently adopted by Chinese enterprises, which is the nature of supply-side structural reform. Without substantial changes in the enterprises' modes of production or innovation in key components, those capacity, costs and fees reduced by the efforts to address overcapacity, reduce inventory, deleverage, lower costs and bolster areas of weakness will be reversed because the supply system cannot match China's demand structure or keep up with the changes in China's social-economic conditions in the future. In this article, the authors believe that innovation in enterprises' modes of production is the key to solve the problems that occur in the period of "New Normal," that is, overcapacity, lack of core technology innovation and mismatching between the supply system and demand structure. Enterprises must focus on developing key components independently, building a development platform for key components, improving their technology development capacity through practices and creating leading designs and standards for key components by making use of China's large market size. China's dynamic demand structure in which standardized and personalized demands coexist may be satisfied by building domestic production networks integrating the integrated innovation-driven core enterprises and modular producers at different levels. Capital fixes may be fulfilled by constructing underground pipe networks in rural areas, which can both eliminate overcapacity and push forward the rural vitalization strategy.

\section{Notes}

1. Xi J. P. (2017), "Zhudong shiying, bawo, yinling jingji fazhan xin changtai, zhuoli tuijin gongjice jiegouxing gage [Actively adapt to, grasp, and lead the new normal of economic development and focus on promoting the supply-side structural reform]", in Literature Research Office of the CPC Central Committee (Ed.), Xi Jinping guanyu shehui zhuyi jingji jianshe lunshu zhaibian [A Selection of Xi Jinping's Discussion on the Construction of Socialist Ecological Civilization], Central Party Literature Press, Beijing, p. 112.

2. Xi J. P. (2017), "Zhudong shiying, bawo, yinling jingji fazhan xin changtai, zhuoli tuijin gongjice jiegouxing gage [Actively adapt to, grasp, and lead the new normal of economic development and focus on promoting the supply-side structural reform]", in Literature Research Office of the CPC Central Committee (Ed.), Xi Jinping guanyu shehui zhuyi jingji jianshe lunshu zhaibian [A Selection of Xi Jinping's Discussion on the Construction of Socialist Ecological Civilization], Central Party Literature Press, Beijing, p. 90.

3. Xi J. P. (2017), "Zhudong shiying, bawo, yinling jingji fazhan xin changtai, zhuoli tuijin gongjice jiegouxing gage [Actively adapt to, grasp, and lead the new normal of economic development and focus on promoting the supply-side structural reform]", in Literature Research Office of the CPC Central Committee (Ed.), Xi Jinping guanyu shehui zhuyi jingji jianshe lunshu zhaibian [A Selection of Xi Jinping's Discussion on the Construction of Socialist Ecological Civilization], Central Party Literature Press, Beijing, p. 90.

4. Xi J. P. (2017), "Zhudong shiying, bawo, yinling jingji fazhan xin changtai, zhuoli tuijin gongjice jiegouxing gage [Actively adapt to, grasp, and lead the new normal of economic development and focus on promoting the supply-side structural reform]", in Literature Research Office of the CPC Central Committee (Ed.), Xi Jinping guanyu shehui zhuyi jingji jianshe lunshu zhaibian [A Selection of Xi Jinping's Discussion on the Construction of Socialist Ecological Civilization], Central Party Literature Press, Beijing, p. 82, p. 105. 
5. Xi J. P. (2017), "Zhudong shiying, bawo, yinling jingji fazhan xin changtai, zhuoli tuijin gongjice jiegouxing gage [Actively adapt to, grasp, and lead the new normal of economic development and focus on promoting the supply-side structural reform]", in Literature Research Office of the CPC Central Committee (Ed.), Xi Jinping guanyu shehui zhuyi jingii jianshe lunshu zhaibian [A Selection of Xi Jinping's Discussion on the Construction of Socialist Ecological Civilization], Central Party Literature Press, Beijing, p. 83.

6. Xi J. P. (2017), "Zhudong shiying, bawo, yinling jingji fazhan xin changtai, zhuoli tuijin gongjice jiegouxing gage [Actively adapt to, grasp, and lead the new normal of economic development and focus on promoting the supply-side structural reform]", in Literature Research Office of the CPC Central Committee (Ed.), Xi Jinping guanyu shehui zhuyi jingji jianshe lunshu zhaibian [A Selection of Xi Jinping's Discussion on the Construction of Socialist Ecological Civilization], Central Party Literature Press, Beijing, p. 83.

7. There are four major shifts in the manufacturing industry, including the shift of some overcapacity from England to the United States in the early 20th century; the shift of traditional industries (e.g. steel, textile) from United States to Japan and Germany in 1950s; the shift of light industry, textile and other industries from developed countries to the Four Asian Tigers (i.e. Hong Kong, Singapore, South Korea and Taiwan) and some Latin American countries between 1960 and 1970s; and the shift of labor intensive industries and low-skill and high energy consuming industries from developed countries and newly industrialized countries to developing countries in 1980s.

8. Xi J. P. (2016), Xi Jinping zai shengbu ji zhuyao lingdao ganbu xuexi guanche dang de shiba jie wuzhong quanhui jingshen zhuanti yantaoban shang de jianghua [President Xi Jinping's Speech at the Thematic Seminar for Main Provincial-Level Leaders to Learn And Implement the Spirit of The Fifth Plenary Session], People's Daily, May 10, p. 1.

9. China Business Times (1998), Gaobie duanque tiaozhan guosheng [No More Shortage and Challenges of Over Supply], August 12.

10. Report Group for China Education and Human Resource Issues (2003), Zhongguo jiaoyu yu renli ziyuan baogao [China Education and Human Resource Report], available at: http://www.cnsaes.org/ homepage/Upfile/201029/2010020977562329.pdf

11. Liu He's Answers for Current Economic and Financial Issues in A Joint Interview with People's Daily reporter Gong Wen, Xinhua reporter Zhao Cheng, CCTV reporter Xu Qiang, available at: http://www.xinhuanet.com/politics/leaders/2018-10/19/c_1123583752.htm

12. Xi J. P. (2016), Xi Jinping zai shengbu ji zhuyao lingdao ganbu xuexi guanche dang de shiba jie wuzhong quanhui jingshen zhuanti yantaoban shang de jianghua [President Xi Jinping's Speech at the Thematic Seminar for Main Provincial-Level Leaders to Learn And Implement the Spirit of The Fifth Plenary Session], People's Daily, May 10, p. 1.

13. Intelligence Research Group (2017), Analysis of the Status Quo and Future Trends of China's Luxury Consumer Industry in 2017, available at: http://www.chyxx.com/industry/201704/516149. html

Compared with CI Consulting's data, Intelligence Research Group's data are relatively conservative, but their differences are very small. According to CI Consulting's calculation, the ratio of Chinese consumers' overseas luxury consumption reached 78 and $77 \%$ in 2015 and 2016 respectively, see Forecast of China's Luxury Market Consumption Scale 2017-2021. Available at: www.sohu.com/a/142516731_255580. This article uses Intelligence Research Group's relatively conservative data.

14. Xi J. P. (2017), "Zhudong shiying, bawo, yinling jingji fazhan xin changtai, zhuoli tuijin gongjice jiegouxing gage [Actively adapt to, grasp, and lead the new normal of economic development and focus on promoting the supply-side structural reform]", in Literature Research Office of the CPC Central Committee (Ed.), Xi Iinping guanyu shehui zhuyi jingij jianshe lunshu zhaibian [A Selection of Xi Jinping's Discussion on the Construction of Socialist Ecological Civilization], Central Party Literature Press, Beijing, p. 75.

15. Li M. (2010), For an overview of 400-million-yuan fund allocation and capital flows, available at: http://info.cm.hc360.com/2010/01/120839153813.shtml 
CPE 3,1

16. Xi J. P. (2017), "Zhudong shiying, bawo, yinling jingji fazhan xin changtai, zhuoli tuijin gongjice jiegouxing gage [Actively adapt to, grasp, and lead the new normal of economic development and focus on promoting the supply-side structural reform]", in Literature Research Office of the CPC Central Committee (Ed.), Xi Jinping guanyu shehui zhuyi jingji jianshe lunshu zhaibian [A Selection of Xi Jinping's Discussion on the Construction of Socialist Ecological Civilization], Central Party Literature Press, Beijing, p. 101.

17. Subcommittee on Advanced Manufacturing Committee on Technology of the National Science and Technology Council (2018), Strategy for American Leadership in Advanced Manufacturing, available at: https:/www.whitehouse.gov/wp-content/uploads/2018/10/Advanced-ManufacturingStrategic-Plan-2018.pdf.

18. Xi J. P. (2017), "Zhudong shiying, bawo, yinling jingji fazhan xin changtai, zhuoli tuijin gongjice jiegouxing gage [Actively adapt to, grasp, and lead the new normal of economic development and focus on promoting the supply-side structural reform]", in Literature Research Office of the CPC Central Committee (Ed.), Xi Jinping guanyu shehui zhuyi jingji jianshe lunshu zhaibian [A Selection of Xi Jinping's Discussion on the Construction of Socialist Ecological Civilization], Central Party Literature Press, Beijing, p. 75.

19. Xi J. P. (2017), "Zhudong shiying, bawo, yinling jingji fazhan xin changtai, zhuoli tuijin gongjice jiegouxing gage [Actively adapt to, grasp, and lead the new normal of economic development and focus on promoting the supply-side structural reform]", in Literature Research Office of the CPC Central Committee (Ed.), Xi Jinping guanyu shehui zhuyi jingji jianshe lunshu zhaibian [A Selection of Xi Jinping's Discussion on the Construction of Socialist Ecological Civilization], Central Party Literature Press, Beijing, p. 98.

20. Gu Y. (18 December 2018), Gongjice jiegouxing gaige chixu fali xian chengxiao [Supply-side Structural Reform Moves On and Shows Results], Economic Daily [Online], available at: http://www. ce.cn/xwzx/gnsz/gdxw/201812/18/t20181218_31054389.shtml.

Guan, Q. Y. (2018), Benefits and Losses for China's Economy Since Supply-side Structural Reform, available at: http://finance.sina.com.cn/zl/china/2018-09-19/zl-ifxeuwwr5862782.shtml.

21. Qiu H. F. (22 December 2018), Gongjice gaige you le "ba zi jue" [Eight-character Guideline for Supply-side Structural Reform], People's Daily Overseas Edition, p. 3.

\section{References}

BCG (2014), "The shifting economics of global manufacturing: how cost competitiveness is changing worldwide", available at: https:/www.bcg.com/publications/2014/lean-manufacturing-globalizationshifting-economics-global-manufacturing.aspx.

Cai, F. (2016a), "Gongjice renshi, xinchangtai, jiegouxing gaige — dui dangqian jingji zhengce de bianxi [Understanding of supply front, new normal, structural reform-analysis of current economic policies]", Tansuo yu Zhengming [Exploration and Free Views], Vol. 22 No. 5, pp. 14-22.

Cai, F. (2016b), "Renshi Zhongguo jinghi jiansu de gongjice shijiao [understanding of China's economic slowdown from the supply-side perspective]", Jingjixue Dongtai [Economic Perspectives], Vol. 31 No. 4, pp. 13-17.

Chen, X.L. and Chen, Y.B. (2016), “Gongjice jiegouxing gaige yu zongxuqiu guanli de guanxi tanxi [Identify the relationship between supply-side structural reform and demand management]", Zhongguo Gaoxiao Shehui Kexue [Social Sciences in Chinese Education Institutions, Vol. 33 No. 3, pp. 67-78.

Chen, J. (2006), "Cong guoji bijiao kan woguo laodongli jiage shuiping de youshi ji qushi [Gauging China's labor price advantages and trends from an international perspective]", Zhongguo Jingmao Daokan [China Economic and Trade Herald], Vol. 23 No. 8, pp. 25-26.

Cheng, X.N. (2018), "Di wubo quanqiu zhizaoye qianyi: cong zhonguo kaishi? [The five major shift of the manufacturing industry: will it start from China?]", Special Broadcasting Service, available at: https:/www.sbs.com.au/yourlanguage/mandarin/zh-hans/article/2018/09/24/guan-dian-diwu-bo-quan-qiu-zhi-zao-ye-qian-yi-cong-zhong-guo-kai-shi?lan-guage $=$ zh-hans. 
Ding, R.Z. (2016), "Guanyu gongjice jiegouxing gaige de zhengzhi jingjixue fenxi [Analysis of the supply-side structural reform from the perspective of political economy]", Jingjixuejia [Economist], Vol. 28 No. 3, pp. 13-15.

Dong, Z.K. (2009), "Xin Zhongguo gongyehua de lujing yu jianshu [The path and achievements of New China's industrialization]", Zhonggong Dangshi Yanjiu [CPC History Studies], Vol. 22 No. 9, pp. 3-14.

Fang, M. and Hu, T. (2016), "Gongjice jiegouxing gaige de zhengzhi jingjixue [Political economy in supply-side structural reform]", Shandong Shehui Kexue [Shandong Social Sciences], Vol. 30 No. 6, pp. 92-98, 134.

Fang, F.Q. and Ma, X.J. (2016), "Zhongguo jingji jiansu de yuanyin yu chulu [Reasons and solutions for China's economic slowdown]", Zhongguo Renmin Daxue Xuebao [Journal of Renmin University of China], Vol. 30 No. 6, pp. 64-75.

Fang, F.Q. (2016), "Gongjice jiegouxing gaige xuyao huida de liangge wenti [Two questions needed to be answers for supply-side structural reform]", Lilun Tansuo [Theoretical Exploration], Vol. 33 No. 3, pp. 5-9.

Fang, F.Q. (2017), "Xunzhao gongjice jiegouxing gaige de lilun yuantou [Seeking the theoretical origins of supply-side structural reform]", Zhongguo Shehui Kexue [Social Sciences in China], Vol. 38 No. 7, pp. 49-69.

Fang, M. (2018), "Zhengzhi jingjixue shijiao xia de gongjice jiegouxing gaige [Supply-side structural reform from the perspective of political economy]", Beijing Daxue Xиebao (Zhexue Shehui Kexue Ban) [Journal of Peking University (Philosophy and Social Sciences)], Vol. 55 No. 1, p. 1.

Gong, G. (2016), "Lun xinchangtai xia de gongjice gaige [Supply-side reform in the era of new normal]", Nankai Xuebao Zhexue Shehui Kexue Ban [Nankai, Journal (Philosophy, Literature and Social Science Edition)], Vol. 23 No. 2, pp. 13-20.

Hammer, M. and Champy, J. (2007), Qiye zaizhao [Reengineering the Corporation], Shanghai Translation Publishing House, Shanghai.

Harvey, D. (1978), "The urban process under capitalism: a framework for analysis", International Journal of Urban and Regional Research, Vol. 2, pp. 101-131.

Hong, Y.X. (2016), "Zhunque renshi gongjice jiegouxing gaige de mubiao he renwu [Understanding of the goal and tasks of the supply-side structural reform]", Zhongguo Gongye Jingii [China Industrial Economics], Vol. 30 No. 6, pp. 14-21.

Hu, A.G., Zhou, S.J. and Ren, H. (2016), “Gongjice jiegouxing gaige-shiying he yinling Zhongguo jingji xin changtai [Structural reform of the supply side - adapt to and lead the new normal of Chinese economy]", Qinghua Daxue Xuebao (Zhexue Shehui Kexue Ban) [Journal of Tsinghua University (Philosophy and Social Sciences)], Vol. 31 No. 2, pp. 17-22.

Hu, Z.Q. (2018), "Wen touzi lidu buyi guomeng duo zhuzhong youxiao jichu sheshi [Stable investment should not go extreme and focus on effective infrastructure]", Hongguan Jingji Guanli [Macroeconomic Management], Vol. 34 No. 10, pp. 36-40, 46.

Huang, Q.H. (2016), "Lun zhonguo gongye de gongjice jiegouxing gaige [On China industrial supplyside structural reform]", Zhongguo Gongye Jingji [China Industrial Economics], Vol. 30 No. 9, pp. 5-23.

Jia, K. and Su, J.C. (2016), "Lun gongjice gaige [On supply-side reform]”, Guangli Shijie [Management World], Vol. 32 No. 3, pp. 1-24.

Jin, B. (2017), "Jiyu jiazhilun yu gongqiulun fanshi de gongjice jiegouxing gaige yanxi [Study on structural reform of the supply front based on the paradigms of theory of value and theory of supply and demand]", Zhongguo Gongye Jingii [China Industrial Economics], Vol. 31 No. 4, pp. 5-16.

Koren, Y. (2015), The Global Manufacturing Revolution, China Machine Press, Beijing.

Li, Y. and Zhang, X.J. (2015), "Xinchangtai':jingji fazhan de luoji yu qianjing ['New normal': the logic and prospect of economic development]", Jingji Yanjiu [Economic Research Journal], Vol. 50 No. 5, pp. 4-19. 
CPE 3,1

Li, X., Liu, X.W. and Wang, Y. (2014), "Yi ge zhonguo jingji fazhan de moxing [A model for China's economic development]", Jingiixue Bao [China Journal of Economics, Vol. 1 No. 4, p. 1.

Li, D.K. (2015), "Guanyu gongjice jiegouxing gaige [On supply-side structural reform]", Lilun Shiye [Theoretical Horizon], Vol. 23 No. 12, pp. 16-19.

Li, J.W. (2018), "Zhongguo jingji zengzhang si shi nian huigu yu zhanwang [Review and prospect of China's economic growth in 40 years]", Guanli Shijie [Management World], Vol. 34 No. 10, pp. 11-23.

Lin, J.H. (2009), "Mokuaihua shengchan fangshi de yingxiang-yi qiche ye mokuaihua shengchan wangluo fazhan wei li [Effect of the mode of module production - a case study on module production network development in the automobile industry]", Zhongguo Jingji Wenti [China Economic Studies], Vol. 51 No. 4, pp. 37-42.

Lin, Y.F. (2016a), "Gongjice gaige de duanqi chongji yu wenti yanjiu [The short-term shock and case study of supply-side reform]", Henan Shehui Kexue [Henan Social Sciences], Vol. 24 No. 1 , pp. 2-4.

Lin, Y.F. (2016b), "Jingji fanghuan zhuyao bu shi tizhi jizhi wenti [Economic slowdown is not caused by systems or mechanisms]", Lilun Cankao [Journal of Theoretical Reference, Vol. 16 No. 5, pp. $76-80$.

Liu, W. and Cai, Z.Z. (2017), "Wanshan guomin shouru fenpei jiegou yu shenhua gongjice jiegouxing gaige [Improving the structure of national income distribution and deepening supply-side structural reform]", Jingii Yanjiu [Economic Research Journal], Vol. 52 No. 8, pp. 4-16.

Liu, W. and Cai, Z.Z. (2018), "Ruhe kandai Zhongguo rengran shi yige fazhanzhong guojia [How to perceive that China is still a developing country?]", Guanli Shijie [Management World], Vol. 34 No. 9, pp. 1-15.

Liu, R.M. and Shi, L. (2011), "Shangyou longduan, feiduichen jingzheng yu shehui fuli-jianlun guoyou dazhongxing qiye lirun de xingzhi [Upstream market monopoly, asymmetric competition and social welfare: on the nature of the large and medium soes' profit]", Jingii Yanjiu [Economic Research Journal], Vol. 46 No. 12, pp. 86-96.

Liu, S.J. (2016a), “Zhongguo jingji zhuanxing zaipingheng qujueyu sange tiaojie [China's economic transformation and rebalancing depends on three conditions]", Lilun Cankao [Journal of Theoretical Reference], Vol. 16 No. 5, pp. 44-66.

Liu, Y.C. (2016b), "Lun gongjice jiegouxing gaige de lilun jichu [A theoretical basis for the supply-side structural reform]", Lilun Daobao, Vol. 16 No. 3, pp. 16-19.

Liu, W. (2016c), "Jingji xin changtai yu gonjice jie gouxing gaige [Economic new normal and supplyside structural reform", Guanli Shijie [Management World], Vol. 32 No. 7, pp. 1-9.

Liu, X.H. (2016d), "Gongjice jiegouxing gaige zhutui Zhongguo jingjizengzhang [The supply-side structural reforms will promote China's economic growth]", Xueshu Yuekan [Academic Monthly], Vol. 48 No. 4, pp. 54-62.

Liu, W. (2017), "Gongjice jiegouxing gaige: lishi keguanxing, tuchu tedian ji zhidu chuangxin yaoqiu [Supply-side structural reform: historical objectivity, outstanding features, and institutional innovation requirements]", Hebei Jingmao Daxue Xuebao [Journal of Hebei University of Economics and Business], Vol. 38 No. 1, pp. 1-4.

Liu, M.Q. (2018), "Shijie shengchan tixi de jubian yu fazhanzhong guojia de jiyu [Drastic changes in the world's manufacturing system and what happens to developing countries]", Tansuo yu Zhengming [Exploration and Free Views], Vol. 33 No. 7, pp. 4-11.

Lo, D. (2018), "Consideration on China's new normal economic growth", Journal of China and International Relations, Vol. 6 No. 1, pp. 73-94.

Lu, F. (2006), Zouxiang zizhu chuangxin: xunqiu Zhongguo liliang [Independent Innovation: Seeking Chinese Power], Guangxi Normal University Press, Guilin.

Lu, F. (2018), "Lun chanpin kaifa pingtai [On product development platform]", Guanli Shijie [Management World], Vol. 34 No. 8, pp. 106-129. 
Marx, K. (2004), Capital: Volume II, People's Publishing House, Beijing.

Pang, J.J. (2016), "Jingji fazhan xin changtai zhong de zhuyao maodun he gongjice jiegouxing gaige [Major contradictions of new normal for economic development and supply-side structural reform]", Zhengzhi Jingjixue Pinglun [Review of Political Economy], Vol. 14 No. 2, pp. 49-59.

Pine, B. (2000), Da guimo dingzhi [Mass Customization: The New Frontier in Business Competition], China Remin University Press, Beijing.

Shapiro, C. and Varian, H. (2000), Xinxi guize: wangluo jingji de celve zhidao [Information Rules: A Strategic Guide to the Network Economy], China Remin University Press, Beijing.

Shen, K.R. and Jin, G. (2016), "Yi tisheng quanyaosu shengchanlyu wei zhongdian tuijin gongjice jiegouxing gaige [Push forward the supply-side structural reform by focusing on total factor productivity]", Nanjing Caïing Daxue Xuebao [Journal of Nanjing University of Finance and Economics, Vol. 23 No. 3, pp. 1-4.

Shen, K.R. and Li, Z. (2017), "Gongjice jiegouxing gaige beijing xia zhizaoye zhuanxing shengji yanjiu Research on manufacturing transformation and upgrading against the background of supplyside structural reform]", Zhongguo Gaoxiao Shehui Kexue [Social Sciences in Chinese Higher Education Institutions, Vol. 30 No. 1, pp. 64-73.

Shen, K.R. (2016), "Gongjice jiegouxing gaige shi jingji zhili silu de zhongda tiaozheng [Supply-side structural reform is the significant adjustment for the idea of economic governance]", Nanjing Shehui Kexue [Nanjing Journal of Social Sciences, Vol. 27 No. 2, pp. 1-3.

Sun, Y.L. and Wen, H.W. (2017), "Woguo zhizaoye channeng guosheng wenti yanjiu [Research on the excess capacity over Chinese manufacturing sector]", Tongji Yanjiu [Statistical Research], Vol. 34 No. 3, pp. 76-83.

Sun, J.W. and Yao, P. (2014), "Jiyu kongjian yizhixing shijiao xia de Zhongguo quyu jingji chayi yanjiu [Research on China's regional economic differences from the perspective of spatial heterogeneity]", Shanghai Jingii Yanjiu [Shanghai Journal of Economics], Vol. 34 No. 5, pp. 83-92.

Tian, G.Q. and Chen, X.D. (2015), “Zhongguo jingji xinjieduan de fazhan qudong zhuanxing yu zhidu zhili jianshe [Development-driven transformation and institutional governance in the new stage of China's economy]", Zhongyang Dangxiao Xuebao [Journal of the Party School of the Central Committee of the C.P.C.], Vol. 28 No. 5, pp. 71-81.

Tian, G.Q. (2018), "Zhongguo jingji zengzhang xiahua de yuanyin [Causes for China's economic growth slowdown]", Xuexi yu Tansuo [Magazine Office of Study and Exploration], Vol. 31 No. 4, pp. 5-15.

Unger, R.M. (2018), "Jinrong weiji yu zhishi jingji shidai de laozi guanxi [The capital-labor relation in the financial crisis and the era of knowledge economy]", Wenhua Zhongheng [Beijing Cultural Review], Vol. 9 No. 3, pp. 50-59.

Wang, X.L., Yan, H.P. and Liu, F. (2014), "Zhongguo quyu jingji zengzhang chayi de shijian yanjin ji kongjian jizhi fenjie: 1952-2012 [Analysis of the time progress and spatial mechanism of growth differences in China's regional economy: 1952-2012]", Dangdai Jingii Kexue [Modern Economic Science], Vol. 36 No. 3, pp. 1-10.

Wang, Y. (2017), "Chuizhi jiegou' xia de guoyou qiye gaige [Vertical structure of state-owned enterprise reform]”, Guoji Jingii Pinglun [International Economic Review, Vol. 40 No. 5, pp. 9-28.

Wang, X.L. (2018), "Gaige 40 nian yu Zhongguo jingji de weilai [40 years of reform and the future for China's economy]”, Xin Jinrong [New Finance], Vol. 35 No. 7, pp. 25-30.

Wei, X.H. and Huang, L.Y. (2018), "Zhengque renshi gongjice jiegouxing gaige de jige lilun wenti [Correctly understanding several theoretical questions on supply-side structural reform]", Lilun yu Pinglun [Theory and Review], Vol. 1 No. 1, pp. 42-47.

Wei, S. (2014), "Shijie jingji de xingeju yu Zhongguo jingji de changqi zengzhang qianjing [The new pattern of world economy and long-term growth prospect of China's economy]", Nanfang Jingji [South China Journal of Economics, Vol. 32 No. 2, pp. 1-23.

Supply-side structural reforms 
CPE

3,1

Wei, S. (2017), "Cong hongguan shuju kan Zhongguo jingji de dangxia geju yu changqi zengzhang qianjing [Status quo and long-term growth prospect of China's economy based on macro data]", Caijing Wenti Yanjiu [Research on Financial and Economic Issues], Vol. 39 No. 4, pp. 3-10.

Wei, X. (2018), "Weiwushig uan shiyu xia 'gongjice jiegouxing gaige' de lilun luoji [The theoretical logic of supply-side structural reform from the perspective of historical materialism]", Shehui Kexue Qianxian [Social Science Front], Vol. 41 No. 4, pp. 20-26.

Wu, J.L. (2016), "Shenme shi jiegouxing gaige?Ta weihe ruci zhongyao? [What is structural reform? Why is it so important?]", Qinghua Guanli Pinglun [Tsinghua Business Review], Vol. 4 No. 11, pp. 8-16.

Wu, J.L. (2017), Bawo jiegouxing gaige, xian cong liuge fangmian tupo [Structural Reform Should Seek Breakthroughs in Six Areas], Xinhua ribao [Xinhua Daily], p. 14.

Xie, F.S. and Li, Z. (2016), "Zhongguo jingji zhong de yiban lirunlv:1994-2011 [The general margins in China's economy: 1994-2011]", Caijing Lilun Yanjiu [Journal of Financial and Economic Theory], Vol. 41 No. 3, pp. 1-8.

Xie, D. and Yu, Q.Y. (2016), "Yong makesi zhuyi zhengzhi jingjixue zhidao gongjice jiegouxing gaige [Guide supply-side structural reform with marxist political economy]", Makesi Zhuyi yu Xianshi [Marxism and Reality], Vol. 30 No. 1, pp. 20-25.

Xie, F.S. (2006), “Qiye wangluo: jijin xuezhe de fenxi fanshi [Corporate network: aggressive scholars' analysis paradigm]", Jingil Lilun yu Jingji Guanli [Economic Theory and Business Management], Vol. 40 No. 7 , pp. 25-30.

Xie, F.S. (2018), "Ruhe lijie Zhongguo tese shehui zhuyi xinshidai shehui zhuyao maodun de zhuanhua [How to understand the change of major social conflict in the new era of socialism with chinese characteristics]", Jiаохие yи Yanjiu [Teaching and Research], Vol. 55 No. 9, pp. 5-14.

Yang, J.G. and Zhu, D.B. (2018), "Makesi jiegou junheng lilun yu Zhongguo gongjice jiegouxing gaige [Marx's structural equilibrium theory and China's supply-side structural reform]", Shanghai Jingii Yanjiu [Shanghai Journal of Economics], Vol. 40 No. 1, pp. 5-16, 26.

Yang, Q.J. (2014), "Lijie guoyou jingji: chanye kongzhi de zhengzhi jingjixue shijiao [Understand stateowned economy: industrial control from the perspective of political economy]", Xueshu Jie [Academics], Vol. 34 No. 7, pp. 19-21.

Zhang, S.H. and Jiang, W.J. (2017), "Zhongguo de channeng guosheng: chengdu cesuan yu hangye fenbu [China's overcapacity: degree calculation and industrial distribution]", Jingji Yanjiu [Economic Research Journal], Vol. 52 No. 1, pp. 89-102.

Zhang, C.S. and Zhang, B.T. (2016), "Zhongguo shiye touzilv xiajiang zhimi:jingji jinronghua shijiao [The secret of the decline in China's Industrial investment: from the perspective of economic finance]", Jingji Yanjiu [Economic Research Journal], Vol. 52 No. 12, pp. 32-46.

Zhang, J. (2016), "Hongguan jingji yu hongjice jiegouxing gaige [Macroeconomics and supply-side structural reform]", Jiangnan Luntan [Jiangnan Forum], Vol. 27 No. 5, pp. 4-6.

Zhang, J.S. (2017), "Yong makesi zaishengchan lilun zhidao woguo de gongjice jiegouxing gaige [Guide China's supply-side structural reform with Marx's reproduction theory]', Dangdai Jingji Yanjiu [Contemporary Economic Research], Vol. 261 No. 7, pp. 29-35.

Zhang, J.K. (2018), 'Ziben xiaxiang' neng zhenxing jingji ma? [Can 'capital going to the countryside' revitalize rural economy?”, available at: https://mp.weixin.qq.com/s/6kpXGwvxtbiCoe8KCiqLgQ.

Zhou, M. and Liu, B.L. (2017), "Gongjice jiegouxing gaige weishenme shi bi you zhi lu? [Why we must implement supply-side structural reform?]”, Jingji Yanjiu [Economic Research Journal], Vol. 52 No. 2, pp. 67-81.

Zhou, M. and Sheng, Y.X. (2018), "Hulianwang shidai gongjice jiegouxing gaige de zhudaoxing dongli: gongyehua chuantong silu de juxian [Leading driver for supply-side structural reform in the era of internet: limits in traditional industrial thought]", Zhongguo Gongye Jingji [China Industrial Economics], Vol. 24 No. 4, pp. 39-58.

Zhou, Y.A. (2015), "Zhongguo zhizaoye de kunjing yu chulu [The dilemma and solution of China's manufacturing industry]", Zhongguo Jinrong [China Finance], Vol. 54 No. 13, pp. 48-50. 
Zou, J.J. and Liu, J.S. (2017), "Woguo yiban lirunlyu cedu ji qushi fenxi [China's general margin measurement and trend analysis]", Jinan Xuebao (Zhexue Shehui Kexue Bao) [Jinan Journal (Philosophy and Social Sciences), Vol. 39 No. 9, pp. 57-65.

\section{Corresponding author}

Fusheng Xie can be contacted at: doc_xfs@sina.com.cn

For instructions on how to order reprints of this article, please visit our website: www.emeraldgrouppublishing.com/licensing/reprints.htm Or contact us for further details: permissions@emeraldinsight.com 